\title{
Using sorghum flour as part substitute of wheat flour in noodles making
}

\begin{abstract}
The study was conducted to evaluate the quality of noodles made from sorghumwheat composite flour with higher percentage of sorghum. The flour samples had $2 \%$ food gum (CMC) in them and the blends were in the ratio $100 \%$ sorghum (SW1), 80:20 (SW2) 70:30 (SW3); 60:40 (SW4), 50:50 (SW5) and 100\% wheat (SW6). The flour samples were used to produce noodles which were subjected to sensory evaluation using nine point hedonic scales. Flour sample SW1 (containing 100\% sorghum) had the highest water absorption capacity (WAC), Oil absorption capacity, gelatinization temperature, emulsion and foaming capacity and bulk density. Noodle samples SW4 and SW5 were not significantly different $(\mathrm{P}>0.05)$ from each other in all sensory parameters. Noodle sample SW6 had the highest fibre content and fat content of $1.38 \%$ and $16.71 \%$ respectively. Noodle sample SW2 recorded the highest carbohydrate content $69.32 \%$ while the control SWT had the highest protein content, $8.91 \%$. There were significant differences $(\mathrm{P}<0.05)$ in all noodle samples as regards to their fibre content. In terms of sensory properties, the noodle samples with higher proportion of sorghum scored low. The results obtained showed general acceptance of the SWT (commercial noodle) samples, followed by samples SW6 and SW5. Sorghum can be substituted in wheat flour from $60 \%$ and below, this would improve noodle variety, make noodles more cheap and available and also reduce dependency on wheat importation; in turn conserving our foreign exchange.
\end{abstract}

Keywords: composite flours, functional properties, noodles, sensory properties, sorghum, wheat
Volume 5 Issue 2 - 2017

\author{
Akajiaku LO, Nwosu JN, Kabuo NO, \\ Odimegwu EN, Umelo MC, Unegbu VC \\ Department of Food Science and Technology, Federal University \\ of Technology, Nigeria
}

Correspondence: Akajiaku LO, Department of Food Science and Technology, Federal University of Technology, PMB I526, Owerri, Imo State, Nigeria, Email lindaoakajiaku@gmail.com

Received: March II, 2017 | Published: November 01, 2017
Abbreviations: CMC, carboxyl methylcellulose; ANOVA, a one way analysis of variance; LSD, least significant difference; FUTO, federal university of technology owerri; DM, dry matter; SW, sorghum wheat; $\mathrm{MC}$, moisture content; $\mathrm{BD}$, bulk density; WAC, water absorption capacity; SI, swelling index; FC, foaming capacity; OAC, oil absorption capacity; EC, emulsion capacity; GT, gelatinization temperature

\section{Introduction}

Noodles are foods with high acceptability worldwide because they are part of the diet of many populations and are relatively inexpensive and easy to prepare. ${ }^{1}$ Instant noodles are mostly fried noodles which are made of flour, water, alkaline salt and other additives. The consumption of instant noodles is global due to their characteristics such as convenience to eat, easy to mass-produce, widely acceptable taste, preferred texture and affordable prices. ${ }^{2}$

To meet consumer demands for increased eating quality and diverse functionality of food, many additives have been developed and are used in pasta and noodle products. These include: Protein supplements to serve as gluten fortifier to give better cooking and nutritional characteristics; emulsifiers and edible gums to improve the surface properties and eating qualities; antioxidants and preservatives to prevent deterioration of colour and extend the microbial shelflife of fresh pasta and noodles; various plant-base or animal-based supplements like dietary fibers, legume flour, buckwheat flour, whey and egg white powder, nutraceuticals, herbal products and even some polyunsaturated fatty acids. Additives have become very important in the growth of modern pasta and noodles processing technology. ${ }^{3}$
Texture is a critical characteristic of noodles and many ingredients such as starch, water, protein and additives like gum play important roles in defining the textural properties. ${ }^{2}$ Guar gum is a commonly used stabilizer in noodle making to provide viscosity, improve firmness; body and mouth feel in the final noodles. Through their ability to bind water, food gums reduce the oil absorption of fried instant noodles and also increases the rehydration rate of instant noodles upon cooking or soaking. ${ }^{4}$

Noodles, pastas and baked products sometimes are made with composite flour to improve certain properties of the product. Composite flour is a mixture of several flours obtained from tubers, cereals and legumes with or without the addition of wheat flour., ${ }^{5,6}$ Composite flour is considered advantageous in developing countries as it reduces the importation of wheat flour and encourages the use of locally grown crops as flour. ${ }^{7,8}$ Apart from being a good source of calories and other nutrients, wheat is considered nutritionally poor, as it is deficient in some essential amino acids such as lysine and threonine. ${ }^{9}$ So, the supplementation of wheat flour with flours from inexpensive staples, such as cereals and pulses, helps improve the nutritional quality of wheat products. ${ }^{10}$

Wheat (Triticum spp.) is a cereal grain, botanically a type of fruit called a caryopsis, ${ }^{11}$ originally from the levant region of the near East but now cultivated worldwide. Globally wheat is the leading source of vegetable protein in human food, having a higher protein than other major cereals, maize, or rice. ${ }^{12}$ Wheat is used to meet consumer demands for bread and other food products in the humid tropics. ${ }^{13}$ There have also been, in recent times, new or improved uses of wheat according to Neil et al., ${ }^{14}$ which includes in the production of wheat 
beer, meat substitutes from wheat, chips, tortillas, coffee and tea substitutes from wheat.

On composition, $100 \mathrm{~g}$ of hard red winter wheat contain about $12.6 \mathrm{~g}$ of protein, $1.5 \mathrm{~g}$ of total fat, $71 \mathrm{~g}$ of carbohydrate, $12.2 \mathrm{~g}$ of dietary fibre and $3.2 \mathrm{mg}$ of iron (17\% of the daily requirement), the same weight of hard red spring wheat contains about $15.4 \mathrm{~g}$ of protein, $1.9 \mathrm{~g}$ of total fat, $68 \mathrm{~g}$ of carbohydrate, $12.2 \mathrm{~g}$ of dietary fibre and $3.6 \mathrm{mg}$ of iron ( $20 \%$ of the daily requirement). ${ }^{12}$

Sorghum (Sorghum bicolar (L) Moench) grain commonly known as Guinea corn is the fifth major staple cereal after wheat, rice, maize and barley. It is cultivated worldwide in warmer climates and is an important food crop in semi-arid areas of Africa, Asia and Central America. ${ }^{15}$ Sorghum grain is a small, hard caryopsis, bears 25,000 to $60,000 / \mathrm{kg} .{ }^{15}$ The common names of Sorghum bicolor L. Moench include; sorghum, brown corn, grain sorghum, milo, durra (English); sorgho, sorghofourager, gros mil (French), Mohrenhirse, Durralcous, Guinea korn (Germany); sorgho, milo-zaburo (Portuguese); sorgo, zahina (Spanish); jowar, jowari (Hindi), amongst other names from other localities. ${ }^{16}$

The whole grain can be boiled, roasted, popped or ground to make flour for baking and pastry. Sorghum grain is used for the production of flat breads, pancakes, porridges, alcoholic beverages including beer and liquors. ${ }^{15}$ In Nigeria, sorghum is used for making pap ("ogi" or "akamu") and koko, which can be used as weaning foods in the Eastern, Western, Northern and Southern parts of the country. ${ }^{17-20}$ In nutritional composition, Sorghum (Guinea corn) contains about the same and sometimes more protein than many other grains. A $1 / 4$ cup serving of guinea corn contains $5 \mathrm{~g}$ of protein, $36 \mathrm{~g}$ of carbohydrate, $4 \mathrm{~g}$ of fibre, $1.6 \mathrm{~g}$ total fat, $13 \mathrm{mg}$ of calcium, $2.1 \mathrm{mg}$ of iron, and $138 \mathrm{mg}$ of phosphorus and $168 \mathrm{mg}$ of potassium. ${ }^{12}$

In Nigeria, Sorghum (Guinea corn) is generally underutilized as it is mostly valued and preferred by the Northerners. There is also a high dependency on wheat to make instant noodles which increases the money spent on importation of wheat, again considering the fact that wheat consumption can increase the rate of celiac disease in gluten intolerant individuals. Also, malnutrition is on the increase in Nigeria and other developing countries of the world due to high dependency on starchy staples.

Therefore, the objectives of this research work are to determine the functional and proximate properties of Sorghum-Wheat composite flours and to evaluate the proximate and sensory properties of the noodle samples made from Sorghum-Wheat composite flours.

Since Nigeria is among the top ranking producers of Sorghum (Guinea corn) which is nutritious, the production of noodles with $100 \%$ sorghum and/or the production of composite flour of sorghum and wheat for the production of the noodles will be an added advantage as it will reduce the dependency on wheat, reduce the money spent on importation of wheat flour thereby saving up to $50 \%$ of what is spent previously as sorghum cost $50 \%$ less than wheat, encourage the utilization of locally available material/locally grown crops as flour (Guinea corn) and also reduce the malnutrition rate in the country.

\section{Materials and methods}

High quality grade yellow Sorghum (Sorghum bicolor) was purchased from Jos, Plateau State Nigeria. Wheat flour, salt and eggs were purchased from a local market in Owerri, Imo State. Carboxyl methylcellulose (CMC), Sodium Carbonate, and Potassium carbonate were purchased from a chemical shop in Lagos State, Nigeria. Equipment, other chemicals (reagents) and facilities used in the research work were obtained from the laboratories of the Department of Food Science and Technology, Federal University of Technology, Owerri, Imo state.

\section{Production of noodle samples}

The noodle production was done based on the Asian style of production. The varied samples were prepared by mixing all the ingredients (Table 1) such as Sorghum-wheat flour, salt, egg, etc., for all samples. After mixing, the dough samples were needed for uniformity and then rested for thirty minutes to 'set'. Prior to slitting and steaming, the dough samples were rolled, sheeted and extruded through a suitable die (width, 1-6mm; height, $1.8 \mathrm{~mm}$ ) which slits/ cuts the samples to have desired size of extrudates. Extruded noodles were steamed in a steamer for $10 \mathrm{~min}$ at $102^{\circ} \mathrm{C}-105^{\circ} \mathrm{C}$ and distributed over wire mesh tray for drying (frying). Dried noodle was packaged in LDPE pack after cooling at room temperature. The flow diagram for the production of the instant noodle samples is shown in Figure 1.

\section{Sorghum-wheat flour + other ingredients}

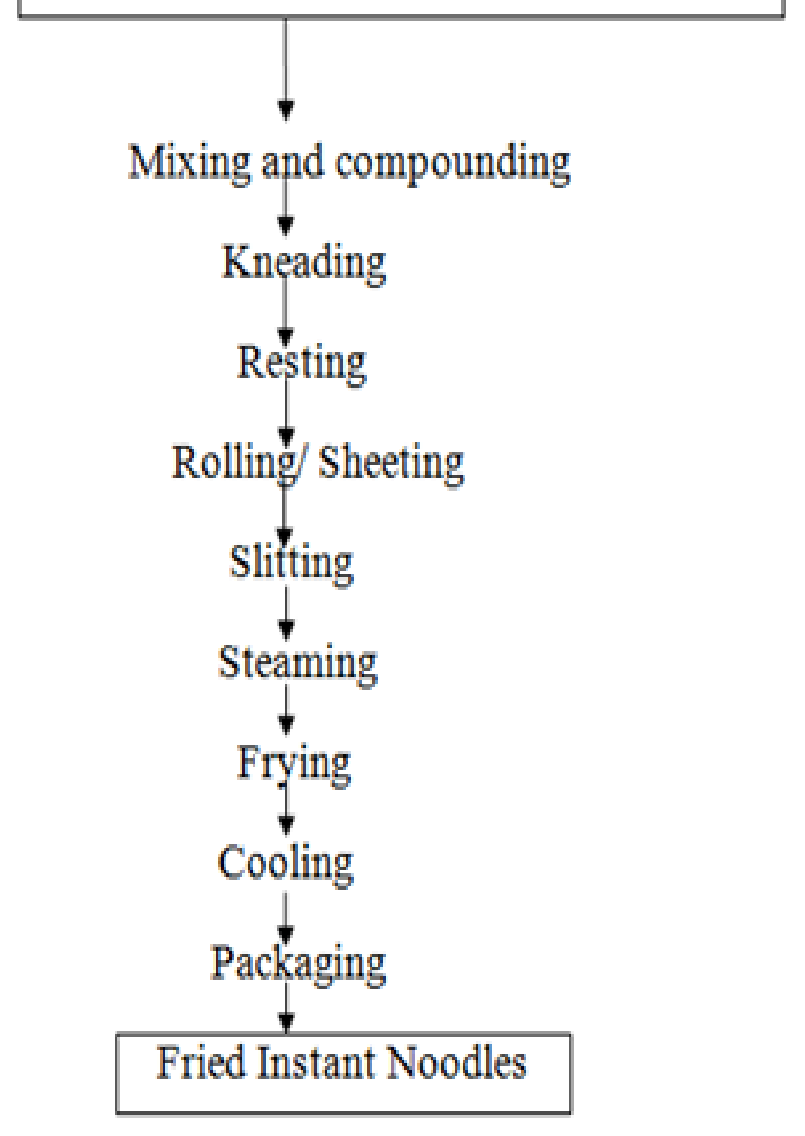

Figure I Flow diagram for the production of instant noodle samples.

Proximate analyses of the composite flour samples and the instant noodle samples

The proximate analyses of the samples were carried out using 
standard methods of Association of Official Analytical Chemists ${ }^{21}$ and Carbohydrate was determined by difference.

Table I Formulation of sorghum-wheat noodles

\begin{tabular}{lll}
\hline Raw material/ingredient & Percentage proportion (\%) & Quantity (g) \\
\hline Sorghum-Wheat (SWI) & $100: 0$ & $(500+0)=500$ \\
Sorghum-Wheat (SW2) & $80: 20$ & $(400+100)=500$ \\
Sorghum-Wheat (SW3) & $70: 30$ & $(350+150)=500$ \\
Sorghum-Wheat (SW4) & $60: 40$ & $(300+200)=500$ \\
Sorghum-Wheat (SW5) & $50: 50$ & $(250+250)=500$ \\
Sorghum-Wheat (SW6) & $0: 100$ & $(0+500)=500$ \\
Egg & 15 & 75 \\
Food gum (CMC) & 2 & 10 \\
Iodized salt & 0.5 & 2.5 \\
Alkaline salts & 1 & 5 \\
(NaCO ${ }_{3}$ and $\left.\mathrm{KCO}_{3}\right)$ & $(1: 1)$ & $\left(2.5 \mathrm{NaCO}_{3}+2.5 \mathrm{KCO}_{3}\right)$ \\
Water & 40 & 200 \\
\hline
\end{tabular}

\section{Functional properties of the composite flour samples}

Determination of bulk density: The method described by AOAC ${ }^{12}$ was adopted. A clean dry measuring cylinder was filled with the flour sample and the bottom of the cylinder was tapped repeatedly until the level could no longer fall below the $100 \mathrm{~cm}^{3}$ marks. The new weight of the sample which occupied $100 \mathrm{~cm}^{3}$ was measured and expressed in ratio of the initial volume. The bulk density was given by:

$$
\text { BulkDensity }=\frac{W}{V} \mathrm{~g} / \mathrm{cm}^{3}
$$

Determination of water absorption capacity: The method described by Onwuka ${ }^{22}$ was adopted. One (1) gram of each sample was put into a test tube and mixed with $10 \mathrm{ml}$ of distilled water. The mixture was left to stand for $30 \mathrm{~min}$ at room temperature before being shaken every $10 \mathrm{~min}$. At the end, it was blended using the magnetic stirrer for $5 \mathrm{~min}$. The supernatant was carefully measured in a graduated cylinder and the volume was used to measure the volume of water absorbed by the sample.

$$
\text { WaterAbsorptionCapacity }=\frac{\left(V_{1}-V_{2}\right) p}{\text { WeightofSample }}
$$

Where;

$\mathrm{V}_{1}=$ Initial volume of water used

$\mathrm{V}_{2}=$ Volume of water not absorbed

$\mathrm{P}=$ Density of water $\left(1.0 \mathrm{~g} / \mathrm{cm}^{3}\right)$

Determination of swelling index: Three (3) gram of each of the flour samples was transferred into clean, graduated $(50 \mathrm{ml})$ cylinder and the volume noted. Distilled water $(30 \mathrm{ml})$ was added to the flour samples; the cylinder was swirled and allowed to stand for $60 \mathrm{~min}$ while change in volume (swelling) was recorded every $15 \mathrm{~min}$. The swelling power of the sample was calculated as a multiple of the original volume as done by Ukpabi et al. ${ }^{23}$

Determination of emulsion capacity: The method as described by $\mathrm{AOAC}^{21}$ was adopted. Four (4)g of each sample of flour and $200 \mathrm{ml}$ of distilled water were blended at room temperature for $30 \mathrm{sec}$ with a Philips blender at $1600 \mathrm{rpm}$. After complete dispersion, vegetable oil was added continuously in $5 \mathrm{ml}$ portions from a burette. Blending continued until the emulsion break point (where a separation into two layers/phases) was observed. The emulsion capacity was expressed as $\mathrm{ml}$ of oil emulsified per gram of sample and was expressed in percentage value.

$$
\text { EmulsionCapacity }(\%)=\frac{V_{E}}{V} \times \frac{100}{W}
$$

Where;

$$
\begin{aligned}
& V_{E}=\text { Volume of Emulsion } \\
& W=\text { Weight of sample } \\
& V=\text { Total volume of mixture }
\end{aligned}
$$

Determination of gelation temperature: The method of Narayana et al. $^{24}$ was adopted in the determination of gelling temperature. Ten (10)gram of each of the flour sample was dispersed in distilled water in a $250 \mathrm{ml}$ beaker and made up to $100 \mathrm{ml}$ flour suspension. A thermometer was clamped on a retort stand with its bulk submerged in the suspension with a magnetic stirrer and the system heated. The heating and stirring continued until the suspension began to gel and the corresponding temperature was recorded. The temperature at boiling point was recorded. 
Determination of oil absorption capacity: The procedure described by Onwuka ${ }^{22}$ was used. One (1)g of each sample was mixed with $10 \mathrm{ml}$ of oil for $30 \mathrm{sec}$ in a mixer set at fast speed. The sample was then allowed to stand at room temperature for $30 \mathrm{~min}$. It was then centrifuged at 500rpm using a centrifuge. The volume of the supernatant was noted in a $10 \mathrm{ml}$ graduated cylinder and the density of the oil was also determined. The volume of oil absorbed was multiplied by the density of the oil to determine the weight of oil absorbed.

$$
\text { OilAbsorptionCapacity }=\frac{\left(V_{1}-V_{2}\right) p}{\text { WeightofSample }}
$$

Where;

$$
\begin{aligned}
& \mathrm{V}_{1}=\text { Initial volume of oil used } \\
& \mathrm{V}_{2}=\text { Volume of oil not absorbed } \\
& \mathrm{P}=\text { Density of oil }\left(0.91 \mathrm{~g} / \mathrm{cm}^{3}\right)
\end{aligned}
$$

\section{Sensory evaluation}

A group of 20 panelists were selected from Federal University of Technology Owerri (FUTO) research community and were asked to score the quality attributes of the cooked noodle samples such as taste, aroma, texture, colour and general acceptability of the products. A description 9-point hedonic scale, (where 9 represents like extremely and 1 represented dislike extremely) as described by Ihekoronye et al. ${ }^{25}$ was used to evaluate the product.

\section{Data analyses}

The results of the functional, proximate and sensory analyses were computed in duplicate values and a one-way Analysis of Variance (ANOVA) and Fishers Least Significant Difference (LSD) was used to establish the significance differences among the values at 0.05 level of confidence. The statistical analysis was computed using the program, IBM SPSS version 20.

\section{Result and discussion}

\section{Proximate properties of the flour Samples}

Moisture content: The result of the proximate properties of the flour samples in Table 2 showed that the moisture content of the flour samples ranged between $7.560 \%$ and $8.720 \%$. Sample SW2 and SW3 were not significantly different $(\mathrm{P}>0.05)$ from each other but were significantly different from the others. The moisture content of each flour sample was not high which suggests that the shelf-life will be normal. Esminger et al. ${ }^{26}$ pointed out that the reduction of moisture content of any food during production helps to enhance its suitability and adaptability for further use in food formulation. The result also showed that moisture content of all flour samples was less than $10 \%$ moisture content recommended for safe keeping of flour sample. ${ }^{27}$ The dry matter (DM) of the flour samples ranged between $91.280 \%$ and $92.440 \%$. There was no significant different $(\mathrm{P}>0.05)$ between sample SW2 and SW3 but they differed significantly $(\mathrm{p}<0.05)$ with other samples. Sample SW4 had the highest dry matter value $(92.440 \%)$ due to its low moisture content while sample SW6 had the lowest dry matter value $(91.280 \%)$ due to its high moisture content.

Ash content: The ash content of the flour samples ranged from $1.850 \%-2.450 \%$. The samples were significantly different $(\mathrm{P}<0.05)$ from one another with sample SW1 having the highest value $(2.450 \%)$ and sample SW5, the lowest $(1.850 \%)$. The differences in composition of the samples may have led to the differences in their ash content. Low ash content shows that the sample has a low mineral content. According to Lienel, ${ }^{28}$ the ash content represents the total mineral content in foods and this serves as a viable food for nutritional evaluation.

Crude fibre content: The crude fibre content of the flour samples ranged from $1.410 \%-1.950 \%$ with sample SW1 as the highest and sample SW5 having the lowest value. The samples differed significantly $(\mathrm{P}<0.05)$ from each other. The variation in the crude fibre content of the flour samples may be due to the different compositions of samples. Eddy et al..$^{29}$ pointed out that crude fibre contributes to the health of the gastrointestinal system and metabolic system in man.

Fat content: The fat content of the flour sample ranged from $1.250 \%$ $2.390 \%$. Sample SW1 (100\% sorghum) having the highest value and SW5 (50\% wheat, 50\% sorghum) had the lowest value. The flour samples are significantly different $(\mathrm{P}<0.05)$. The fat content of the blends increased with the increase in the quantity of sorghum in the mixture. The low fat content of the flour samples makes it good for formulation of product with low fat cater for people especially the obsessed.

Crude protein: The crude protein of the samples ranged from $9.500 \%$ to $14.265 \%$. The samples differed significantly $(\mathrm{P}<0.05)$ with sample SW1 having the highest while sample SW5 had the lowest value. It could be said that sample SW1 had more essential amino acid than sample SW6 (100\% wheat flour). Although the protein content of wheat flour is higher than that of sorghum flour but its low in certain amino acids like leucine, tryptophan which is higher in sorghum flour. $\left.{ }^{30}\right]$

Carbohydrate content: From the result, carbohydrate content of samples SW4 and SW5 were not significantly different $(\mathrm{P}>0.05)$ while sample SW1 had the lowest carbohydrate $(70.565 \%)$. The samples contain an ample quantity of carbohydrate which makes them a cheap source of energy for the body.

\section{Functional properties of flour samples}

Bulk density: The results of the functional properties of the samples in Table 3 showed that the bulk density of the samples differed significantly $(\mathrm{P}<0.05)$ from each other. Sample SW1 had the highest bulk density $(0.684 \mathrm{~g} / \mathrm{ml})$. This may be attributed to the fact that it contains a high fat content when compared with the other samples. Sample SW6 had the lowest bulk density $(0.625 \mathrm{~g} / \mathrm{ml})$.

Water absorption capacity: There were significant differences $(\mathrm{P}<0.05)$ among the samples in the water absorption capacity. Water absorption capacity of the composite flour blends ranged from 2.850 to $3.405 \mathrm{~g} / \mathrm{cm}^{3}$. Sample SW1 had the highest water absorption capacity $\left(3.465 \mathrm{~g} / \mathrm{cm}^{3}\right)$ with SW6 having the lowest. According to Iwe ${ }^{31}$ water absorption capacity improves with increase in protein and carbohydrate content of particular flour blends. Water absorption capacity is important in consistency of products as well as backing application. ${ }^{32,33}$ Water absorption capacity represents the ability of a product to associate with water under condition where water is limiting, in order to improve its handling characteristics. ${ }^{34}$

Swelling index: The samples differed significantly $(\mathrm{P}<0.05)$ in swelling index, which range from $2.480 \mathrm{~g} / \mathrm{ml}-2.800 \mathrm{~g} / \mathrm{ml}$. Sample SW4 
had the highest swelling index $(2.800 \mathrm{~g} / \mathrm{ml})$ while SW6 had the lowest swelling index $(2.480 \mathrm{~g} / \mathrm{ml})$. This result may be due to the composition of the samples. Wang et al..$^{35}$ reported that the amount of protein and fat of flour could inhibit the starch granules from swelling. Achinewhu et al. ${ }^{36}$ also reported that high swelling capacity is criteria for a good product.

Foaming capacity: The foaming capacity of the samples ranged from $13.675-15.780 \%$. Sample SW1 had the highest forming capacity $(15.780 \%)$ while sample SW6 had the lowest (13.675\%). There were no significant difference $(\mathrm{P}>0.05)$ in foaming capacity of samples SW2 and SW3 but they differed significantly $(\mathrm{P}<0.05)$ from other samples. The result showed that increase in the protein content of the samples leads to increase in foaming capacity. This is due to the fact that the denaturation and aggregation of proteins during agitation led to foam formation as pointed out by Yadahally et al. ${ }^{37}$

Oil absorption capacity: From the result of the Oil Absorption Capacity (OAC), sample SW3 and SW4 were not significantly different $(\mathrm{P}>0.05$ but differed significantly $(\mathrm{P}<0.05)$ from the other samples. The Oil absorption capacity of the samples SW1 and SW2 were the highest; $1.480 \mathrm{~g} / \mathrm{cm}^{3}$ and $1.450 \mathrm{~g} / \mathrm{cm}^{3}$ respectively. This may be due to their high protein content as reported by Chauhan et al. ${ }^{38}$

Gelation temperature: The Gelatinization Temperature (GT) of the samples ranged from $68.00^{\circ} \mathrm{C}$ to $85.75^{\circ} \mathrm{C}$. The result showed that the samples differed significantly $(\mathrm{P}<0.05)$ amongst them. Sample SW1 had the highest gelatinization temperature with sample SW6 having the lowest. The variation in gelatinization temperature of the samples may be due to the difference in composition especially, the starch contents. According to Rickard et al., ${ }^{39}$ gelatinization affects texture and digestibility of starchy foods.

Emulsion capacity: From the result, the emulsion capacity of the flour samples ranged from 39.280-45.310\%. Sample SW1 had the highest value while sample SW6 had the lowest value. All the samples differed significantly $(\mathrm{P}<0.05$ from each other. Sample SW1 having the highest EC may be due to its high content of protein. Jayaprakasha et $\mathrm{al} .{ }^{40}$ asserted that the unfolding of proteins at the interface of water/ oil plays an important role in the emulsifying capacity due to increased hydrophobicity.

\section{Proximate properties of the instant noodles samples}

The proximate properties of instant fried noodles samples made with different ratios of sorghum-wheat flour are shown in Table 4.

Moisture content: From the result, the control sample, SWT (Tummy Tummy noodle) had the lowest moisture content (4.68\%) while sample SW5 (50\% sorghum, 30\% wheat) had the highest moisture content $(8.15 \%)$. There were no significant difference $(\mathrm{P}>0.05)$ in samples SW1, SW2, and SW6 as regards to moisture content and dry matter $(\mathrm{DM})$, but they differ significantly $(\mathrm{P}<0.05)$ with other samples. This indicates that control sample; SWT will have a longer shelf-life than other samples.

Ash content: The ash content of the noodles ranged from $1.350 \%$ - $1.790 \%$. Samples SW1, SW2 and SW4 were not significantly different $(\mathrm{P}>0.05)$ from each other. Also, samples SW5 and SW6 were not significantly different $(\mathrm{P}>0.05)$, but they differed significantly $(\mathrm{P}<0.05)$ from other samples. The control sample $\mathrm{SW} 1$, had the highest ash content (1.79\%) followed by sample SW6 (100\% wheat) with the value of $1.605 \%$. Sample SW2 (80\% sorghum, 20\% wheat) had the lowest ash content (1.35\%).

Fibre content: From the result, sample SWT had the highest fibre content $(1.57 \%)$ followed by sample SW6 (1.380\%) while sample SW1 (100\% sorghum) had the lowest fibre content (1.140\%).

Fat content: The fat content of the noodle samples ranged from $13.660 \%-16.710 \%$, sample SW2 and SW6 had the lowest and highest respectively. Samples SW3, SW4 and SW5 were not significantly different $(\mathrm{P}>0.05)$ from each other, also samples SW1 and SWT were not significantly different $(\mathrm{P}>0.05)$ from each other. Products with high fat content promote rancidity, which leads to development of off flavour and odour. Also consumption of food products with high fat content could lead to obesity and other ill health conditions. Therefore low fat content in noodles is desirable both to the processor and the consumer.

Protein content: The protein content of the noodle samples ranged from $5.860 \%-8.910 \%$, with samples SW1 and SWT having the lowest and highest values respectively. Samples SW2, SW4 and SW6 were not significantly different $(\mathrm{P}>0.05)$ from each other but differed significantly $(\mathrm{P}<0.05)$ from other samples. Among the flour blends (SW2, SW3, SW4 and SW5), sample SW5 (50\% wheat, 50\% sorghum) had the highest protein content $(7.273 \%)$ followed by sample SW3 (70\% sorghum, 30\% wheat).

Carbohydrate content: The carbohydrate content of the noodle samples ranged from $66.00 \%-69.300 \%$, samples SW5 and SW2 had the lowest and highest values respectively. The control sample SWT had a carbohydrate content of $66.675 \%$ which is low compared to samples SW1, SW2, SW3, SW4 and SW6. This showed that noodles made from sorghum wheat composite flour had higher carbohydrate content than the control sample, SWT. The high carbohydrate content of the noodle samples indicates that they will be a good source of energy for the body.

\section{Sensory properties of the noodle samples}

The mean scores of the sensory properties are shown in Table 5. The result showed that the control sample, SWT, was ranked the best in all parameters followed by SW6 and SW5, sample SW1 and SW2 were the least acceptable noodles.

For texture, sample SW1 and SW2 were not significantly different $(\mathrm{P}>0.05)$ from each other but differed significantly $(\mathrm{P}<0.05)$ from other samples. Samples SW4 and SW5 were not significantly different $(\mathrm{P}>0.05)$ from each other but differed significantly $(\mathrm{P}<0.05)$ from other samples. For aroma, sample SW4 and SW5 were not significantly different $(\mathrm{P}>0.05)$ from each other but differed significantly $(\mathrm{P}<0.05)$ from other samples. For colour, samples SW6 and SWT were not significantly different $(\mathrm{P}>0.05)$ but differed significantly $(\mathrm{P}<0.05)$ from other samples. Samples SW3, SW4 and SW5 were not significantly different $(\mathrm{P}>0.05)$ from one another but differed significantly $(\mathrm{P}<0.05)$ from other samples. For flavor, samples SW4 and SW5 were not significantly different $(\mathrm{P}>0.05)$ from each other but differed significantly $(\mathrm{P}<0.05)$ from other noodle samples. In like manner, noodle samples SW4 and SW5 were not significantly different $(\mathrm{P}>0.05)$ from each other but differed significantly $(\mathrm{P}<0.05)$ with other samples in terms of general acceptability. 
Table 2 Proximate Properties of Sorghum-wheat composite flour samples

\begin{tabular}{lccccccc}
\hline Samples & MC \% & DM \% & Ash \% & Fibre \% & Fat \% & Protein \% & CHO \% \\
\hline SW1 & $8.380^{\mathrm{c}}$ & $91.620^{\mathrm{c}}$ & $2.450^{\mathrm{a}}$ & $1.950^{\mathrm{a}}$ & $2.390^{\mathrm{a}}$ & $14.265^{\mathrm{a}}$ & $70.565^{\mathrm{e}}$ \\
SW2 & $7.810^{\mathrm{d}}$ & $92.190^{\mathrm{b}}$ & $2.1 \mathrm{~b} 5^{\mathrm{c}}$ & $1.565^{\mathrm{c}}$ & $1.380^{\mathrm{d}}$ & $11.490^{\mathrm{b}}$ & $75.020^{\mathrm{c}}$ \\
SW3 & $7.910^{\mathrm{d}}$ & $92.090^{\mathrm{b}}$ & $1.960^{\mathrm{d}}$ & $1.480^{\mathrm{d}}$ & $1.310^{\mathrm{e}}$ & $11.380^{\mathrm{c}}$ & $75.960^{\mathrm{b}}$ \\
SW4 & $7.560^{\mathrm{e}}$ & $92.440^{\mathrm{a}}$ & $1.880^{\mathrm{e}}$ & $1.450^{\mathrm{de}}$ & $1.490^{\mathrm{c}}$ & $10.310^{\mathrm{e}}$ & $77.310^{\mathrm{a}}$ \\
SW5 & $8.560^{\mathrm{b}}$ & $91.440^{\mathrm{d}}$ & $1.850^{\mathrm{f}}$ & $1.410^{\mathrm{e}}$ & $1.250^{\mathrm{f}}$ & $9.500^{\mathrm{f}}$ & $77.410^{\mathrm{a}}$ \\
SW6 & $8.720^{\mathrm{a}}$ & $91.280^{\mathrm{e}}$ & $2.260^{\mathrm{b}}$ & $1.850^{\mathrm{b}}$ & $1.900^{\mathrm{b}}$ & $11.225^{\mathrm{d}}$ & 17.045 \\
LSD & 0.1038 & 0.1038 & 0.0255 & 0.0533 & 0.0245 & 0.067 & 0.1945
\end{tabular}

Mean with same superscript in the same column are not significantly different at $(P>0.05)$. MC, moisture content; CHO, carbohydrate; DM, dry matter; LSD, least significant difference.

Key:

SWI $=100 \%$ Sorghum.

SW2 $=80 \%$ Sorghum, $20 \%$ Wheat.

SW3 $=70 \%$ Sorghum, $30 \%$ Wheat.

SW $4=60 \%$ Sorghum, $40 \%$ Wheat.

SW5 $=50 \%$ Sorghum, $50 \%$ Wheat.

SW6 $=100 \%$ Wheat.

Table 3 Functional Properties of Sorghum-wheat composite flour samples

\begin{tabular}{lccccccc}
\hline Samples & BD g/ml & WAC g/cm & SI g/ml & FC \% & EC \% & GT $\mathbf{C m}^{\circ}$ & OAC $\mathbf{g} / \mathbf{c m}^{3}$ \\
\hline SW1 & $0.684^{\mathrm{a}}$ & $3.465^{\mathrm{c}}$ & $2.760^{\mathrm{b}}$ & $15.780^{\mathrm{a}}$ & $45.310^{\mathrm{a}}$ & $85.750^{\mathrm{a}}$ & $1.480^{\mathrm{a}}$ \\
SW2 & $0.651^{\mathrm{b}}$ & $3.281^{\mathrm{b}}$ & $2.720^{\mathrm{c}}$ & $14.340^{\mathrm{c}}$ & $42.820^{\mathrm{b}}$ & $82.490^{\mathrm{c}}$ & $1.450^{\mathrm{b}}$ \\
SW3 & $0.642^{\mathrm{c}}$ & $3.190^{\mathrm{c}}$ & $2.625^{\mathrm{d}}$ & $14.275^{\mathrm{c}}$ & $42.440^{\mathrm{c}}$ & $85.000^{\mathrm{d}}$ & $1.410^{\mathrm{c}}$ \\
SW4 & $0.634^{\mathrm{d}}$ & $3.120^{\mathrm{d}}$ & $2.800^{\mathrm{a}}$ & $14.610^{\mathrm{b}}$ & $40.835^{\mathrm{d}}$ & $78.250^{\mathrm{e}}$ & $1.415^{\mathrm{c}}$ \\
SW5 & $0.625^{\mathrm{e}}$ & $2.940^{\mathrm{e}}$ & $2.540^{\mathrm{e}}$ & $13.280^{\mathrm{d}}$ & $39.870^{\mathrm{e}}$ & $79.525^{\mathrm{d}}$ & $1.380^{\mathrm{d}}$ \\
SW6 & $0.625^{\mathrm{f}}$ & $2.850^{\mathrm{f}}$ & $2.480^{\mathrm{f}}$ & $13.675^{\mathrm{e}}$ & $39.280^{\mathrm{f}}$ & $68.000^{\mathrm{d}}$ & $1.320^{\mathrm{e}}$ \\
LSD & 0.0014 & 0.0212 & 0.0353 & 0.0713 & 0.1201 & 0.3757 & 0.0255
\end{tabular}

Mean with same superscript in the same column are not significantly different at (P> 0.05). BD, bulk density;WAC, water absorption capacity; SI, swelling index; FC, forming capacity; EC, emulsion capacity; GT, gelation temperature; OAC, oil absorption capacity; LSD, least significant difference

Key:

SWI $=100 \%$ Sorghum.

SW2 $=80 \%$ Sorghum, 20\% Wheat.

SW3 $=70 \%$ Sorghum, 30\% Wheat.

SW4 $=60 \%$ Sorghum, $40 \%$ Wheat.

SW5 $=50 \%$ Sorghum, $50 \%$ Wheat.

SW6 $=100 \%$ Wheat. 
Table 4 Proximate properties of the instant noodle samples

\begin{tabular}{llllllll}
\hline Samples & MC \% & DM \% & Ash \% & Fibre \% & Fat \% & Protein \% & CHO \% \\
\hline SW1 & $6.790^{\mathrm{d}}$ & $93.210^{\mathrm{b}}$ & $1.360^{\mathrm{d}}$ & $1.140^{\mathrm{f}}$ & $16.560^{\mathrm{a}}$ & $5.860^{\mathrm{d}}$ & $68.290^{\mathrm{b}}$ \\
SW2 & $7.600^{\mathrm{b}}$ & $92.300^{\mathrm{d}}$ & $1.350^{\mathrm{d}}$ & $1.320^{\mathrm{c}}$ & $13.660^{\mathrm{c}}$ & $6.340^{\mathrm{cd}}$ & $69.320^{\mathrm{a}}$ \\
SW3 & $6.800^{\mathrm{d}}$ & $93.200^{\mathrm{b}}$ & $1.445^{\mathrm{c}}$ & $1.200^{\mathrm{e}}$ & $15.860^{\mathrm{b}}$ & $6.340^{\mathrm{cd}}$ & $69.320^{\mathrm{a}}$ \\
SW4 & $7250^{\mathrm{c}}$ & $92.750^{\mathrm{c}}$ & $1.370^{\mathrm{d}}$ & $1.240 \mathrm{~d}^{\mathrm{e}}$ & $15.510^{\mathrm{b}}$ & $6.300^{\mathrm{cd}}$ & $68.320^{\mathrm{b}}$ \\
SW5 & $8.150^{\mathrm{a}}$ & $91.850^{\mathrm{e}}$ & $1.545^{\mathrm{b}}$ & $1.280^{\mathrm{cd}}$ & $15.780^{\mathrm{b}}$ & $7.275^{\mathrm{b}}$ & $66.000^{\mathrm{e}}$ \\
SW6 & $6.790^{\mathrm{d}}$ & $93.300^{\mathrm{b}}$ & $1.605^{\mathrm{b}}$ & $1.380^{\mathrm{b}}$ & $16.710^{\mathrm{a}}$ & $6.340^{\mathrm{cd}}$ & $67.265^{\mathrm{cd}}$ \\
SWT & $4.680^{\mathrm{e}}$ & $95.320^{\mathrm{a}}$ & $1.790^{\mathrm{a}}$ & $1.570^{\mathrm{a}}$ & $16.375^{\mathrm{a}}$ & $8.910^{\mathrm{a}}$ & $66.675^{\mathrm{de}}$ \\
LSD & 2.3646 & 0.1019 & 0.0666 & 0.0 .0490 & 0.4475 & 0.1513 & 0.9984
\end{tabular}

Mean with same superscript in the same column are not significantly different at (P>0.05). MC, moisture content; $\mathrm{CHO}$, carbohydrate; $\mathrm{DM}$, dry matter; LSD, least significant difference.

Key:

SWI $=100 \%$ Sorghum

SW2 $=80 \%$ Sorghum, $20 \%$ Wheat.

SW3 $=70 \%$ Sorghum, 30\% Wheat.

SW $4=60 \%$ Sorghum, $40 \%$ Wheat.

SW5 $=50 \%$ Sorghum, $50 \%$ Wheat.

SW6 $=100 \%$ Wheat.

SWT $=$ Commercial Noodle (Control).

Table 5 Mean values for sensory scores of the noodle samples

\begin{tabular}{llllll}
\hline Sample & Texture & Aroma & Colour & Flavour & GA \\
\hline SW1 & $2.00^{\mathrm{e}}$ & $1.00^{\mathrm{f}}$ & $1.40^{\mathrm{d}}$ & $1.30^{\mathrm{e}}$ & $1.40^{\mathrm{f}}$ \\
SW2 & $2.40^{\mathrm{e}}$ & $2.00^{\mathrm{e}}$ & $2.60^{\mathrm{c}}$ & $1.70^{\mathrm{e}}$ & $2.30^{\mathrm{e}}$ \\
SW3 & $3.20^{\mathrm{d}}$ & $2.80^{\mathrm{d}}$ & $5.60^{\mathrm{b}}$ & $3.50^{\mathrm{d}}$ & $3.20^{\mathrm{d}}$ \\
SW4 & $4.20^{\mathrm{c}}$ & $4.30^{\mathrm{c}}$ & $5.80^{\mathrm{b}}$ & $5.50^{\mathrm{c}}$ & $5.40^{\mathrm{c}}$ \\
SW5 & $4.70^{\mathrm{c}}$ & $4.80^{\mathrm{c}}$ & $5.80^{\mathrm{b}}$ & $5.80^{\mathrm{c}}$ & $5.70^{\mathrm{c}}$ \\
SW6 & $5.90^{\mathrm{b}}$ & $5.80^{\mathrm{b}}$ & $7.40^{\mathrm{a}}$ & $6.70^{\mathrm{b}}$ & $6.80^{\mathrm{b}}$ \\
SWT & $7.10^{\mathrm{a}}$ & $7.30^{\mathrm{a}}$ & $7.60^{\mathrm{a}}$ & $7.60^{\mathrm{a}}$ & $7.70^{\mathrm{a}}$ \\
LSD & 1.5823 & 1.2074 & 1.0442 & 1.0472 & 0.9521 \\
\hline
\end{tabular}

Mean with same superscript in the same column are not significantly different at ( $>0.05)$. GA, general acceptability; LSD, least significant difference.

Key:

SWI $=100 \%$ Sorghum.

SW2=80\% Sorghum, $20 \%$ Wheat.

SW3 $=70 \%$ Sorghum, $30 \%$ Wheat.

SW $4=60 \%$ Sorghum, $40 \%$ Wheat.

SW5 $=50 \%$ Sorghum, $50 \%$ Wheat.

SW6 $=100 \%$ Wheat.

SWT=Commercial Noodle (Control).

\section{Conclusion}

The results have shown that noodles with higher percentage of sorghum had low sensory acceptability except for levels of $60 \%$ and $50 \%$ which were neither liked nor disliked. It was observed that the bulk densities of the flour samples were closely related. It was also observed that the noodle samples from the flour blends had good quantity of nutrients that were not too low compared to the control sample (commercial noodles). Thus, sorghum flour can be partly substituted in wheat flour from $60 \%$ and below, this would improve noodle variety, make noodles cost $50 \%$ less than previous amount (cheap) and available and also reduce dependency on wheat importation, conserving our foreign exchange.

\section{Recommendation}

The production of noodles using sorghum-wheat composite flour is highly recommended. Further research should be carried out using lower percentage of sorghum in the composite flour and also using a better edible gum like guar gum and not $\mathrm{CMC}$ to improve the texture. Further treatment can also be given to the sorghum flour to modify the aroma and colour.

\section{Acknowledgements}

None.

\section{Conflicts of interest}

The author declares no conflict of interest. 


\section{References}

1. Silvana BS, Hugo Diego S, Maria AT, et al. Design of a premix for making gluten free noodles. International Journal of Nutrition and Food Sciences. 2014;13(5):488-492.

2. Li JY. Noodle dough rheology and quality of instant fried noodles. Department of Bioresource engineering. Mcdonald Campus, Montreal Quebec, Canada: McGill University; 2003. p. 1-138.

3. Man L, Ke Xue Z, Xiao G, et al. Natural Additives in wheat-based Pasta and noodle products. Opportunities for enhanced Nutritional and functional properties. Comprehensive reviews in food science and food safety. 2013;13(4):347-357

4. Hou GQ. Oriental Noodles. Advances in food and nutrition research 2001;43:140-193.

5. Adeyemi SAO, Ogazi PO. The place of plantain in composite flour Commerce industry. WHO, Rep series 1973. NO 522, Genem Lagos State, Nigeria: WHO; 1985

6. Shittu T, Raji AO, Sanni LO. Bread from composite cassava-wheat flour: I. Effect of baking time and temperature on some physical properties of bread loaf. Food Research International. 2007;40(2):280-290.

7. Hugo LF, Rooney LW, Taylor JRN. Malted sorghum as a functional ingredient in composite bread. Cereal Science. 2000;77(4):428-432.

8. Hasmadi M, Siti FA, Salwa I, et al. The effect of seaweed composite flour on the textural properties of dough and bread. Journal of applied psychology. 2014;26(2):1057-1062.

9. Dhingra S, Jood S. Organoleptic and nutritional evaluation of wheat breads supplemented with soybean and barley flour. Journal of Food Chemistry. 2001;77(4):479-488.

10. Sharma S, Bajwa UH, Nagi HPS. Rheological and baking properties of cowpea and wheat flour blends. Journal Science Food Agriculture. 1999;79(5):657-662.

11. James MD. Wheat Botany. USA: Jones and Barhett publishers; 2014. 23 p.

12. (USDA) United States Department of Agriculture. Nutrient data laboratory. National Nutrient database for standard reference. USA; 2012.

13. Shewry PR, Hey SI. Do we need to worry about wheat? Nutrition bulletin. 2016;41(1):6-13

14. Neil R. Booze: The drinks Bible for the $21^{\text {st }}$ century. Octupus publishing group-cassel illustrated, UK; 2002. 12 p.

15. Escoport. Escoport database; 2009

16. Heuzé V, Tran G, Giger Reverdin S, et al. Sorghum forage. Feedipedia, a programme by INRA, CIRAD, AFZ and FAO; 2015.

17. King J, Ashworth A. Changes in infant feeding practices in Nigeria, an historical review. Occasional Paper No. 9. London: Centre for Human Nutrition, London School of Hygiene and Tropical Medicine; 1987.

18. Longhurst R. The energy trap. Work, nutrition and childhood malnutrition in Northern Nigeria. Division of Nutrition Sciences, Ithaca, New York USA: Cornell University College of Agriculture and Life Sciences; 1984. $101 \mathrm{p}$.

19. Cherian A. Attitudes and practices of infant feeding in Zaria. Ecol Food Nutr. 1981;11(2):75-80.

20. Osuhor PC. practices amongst the Hausas. J Hum Nutr. 1980;34(4):273280
21. AOAC. Official Method of Analysis. 15th ed. Association of official analytical chemists, Washington, USA: DC; 1990.

22. Onwuka GI. Food analysis and instrumentation, theory and practices. Napthali prints, Nigeria; 2015. p. 95-96.

23. Ukpabi UJ, Ndimele C. Evaluation of the quality of garri produced in Imo State Nigeria. Nig Fd J. 1990;8:105-110.

24. Narayana KM, Narasinga Roa MSN. Functional properties of raw and heat processed winged bean (Psohocarpustetragonolubus) flour. $J$ food Sci. 1982;7:1534-1538.

25. Ihekoronye AI, Ngoddy PO. Integrated Food Science and Technology for the Tropics. London: Macmillan Publishers Limited London Publications, 1985. $386 \mathrm{p}$.

26. Esminger ME, Esminger AH, Konlande JE, et al. The concise encyclopedia of food and nutrition. USA: CRC Press; 1995. p. 360-365.

27. SON. Nigerian Industrial Standard for biscuits. ICS: 664.68, Standard Organization of Nigeria; 2007.

28. Lienel HH. Ash analysis. In: Introduction in Chemical Analysis of Food In: Nielson SS editor. New Delhi, India: CBS Publishers; 2002. 972 p.

29. Eddy NO, Udufia PG, Eyo O. Sensory evaluation of wheat/cassava composite bread and effect of label information on acceptance and performance. African journal of Biotechnology. 2007;6(20):2415-2418.

30. Nutritional info: Sorghum vs Wheat flour, white (industrial), $10 \%$ protein, bleached, enriched; 2010 .

31. Iwe MO. Effects of extrusion on some functional properties of soy-sweet potato mixture: A response surface analysis. Plant Food Hum Nutri. 2000;55(2):169-184

32. Oyarekua MA, Adeyeye EI. Comparative evaluation of the nutritional quality, functional properties and amino acid profile of co-fermented maize/cowpea and sorghum/cowpea Ogi as infant complementary food. Asian Journal of Clinical Nutrition. 2009;1(1):31-39.

33. Niba LL, Bokanga MM, Jackson FL, et al. Physicochemical properties and starch granular characteristics of flour from various manihot esculenta (Cassava) Genotypes. J Food science. 2002;67(5):1701-1705.

34. Giami SY, Bekebian DA. Proximate composition and functional properties of raw and processed full fat pumpkin (telfairiaoccidentalis) seed flour. J sci food agric. 1992;59(3):11-325

35. Wang L, Seib PA. Australian salt-noodle flours and their starches compared to US wheat flours and their starches. Cereal Chem. 1996;73(2):167-175.

36. Achinewhu SC, Barber LI, Ijeoma IO. Physiochemical properties and garification (gari yield) of selected cassava cultivars in River State, Nigeria. Plant Foods for Hum Nutr. 1998;52(2):133-140.

37. Yadahally N, Vadakkoot B, Vishwas M. Nutritional implication and flour functionality of popped/ expanded horse gram. J Food Chem. 2008;108(3):891-899.

38. Chauhan GS, Bains GS. Effect of granularity on the characteristics of extruded rice snack. Intl J Food Sci Tech. 1985;20(3):305-309.

39. Rickard JE, Asoaka M, Blanshard JMV. Physio-chemical properties of cassava. Tropical Science. 1991;31:189-207.

40. Jayaprakasha HM, Brueckner $H$. Whey protein concentrate: A potential functional ingredient for food industry. J Food Sci Technol. 1999;36(3):189-204. 